\title{
Morphological and Craniometrical Studies on the Skull of Kagani Goat (Capra hircus) of Jammu Region
}

\author{
Estudios Morfológico y Craniométrico de la Cabra Kagani (Capra hircus) de la Región de Jammu
}

\section{Kamal Sarma}

SARMA, K. Morphological and craniometrical studies on the skull of Kagani Goat (Capra hircus) of Jammu Region. Int. J. Morphol., 24(3):449-455, 2006.

SUMMARY: Forty six heads of adult Kagani goats were used in the present study. The frontal bone did not constitute the caudal extent of the frontal surface. Both the nasal bones were divided longitudinally into two halves by deep notches up to the middle part starting from its rostral end. The facial tuberosity was placed at the junction of the 4th and 5th cheek teeth. The basisphenpoid bone had a sharp median ridge. The frontal bone contributed to the maximum in this animal. Bilateral variation was recorded among the orbits of right and left sides. Skull base length varied positively with the skull width and skull length.

\section{KEY WORDS : Morphology; Craniometry; Goat.}

\section{INTRODUCTION}

The regional anatomy of the head gathers its importance itself due the fact that it lodges such vital organs as the brain, tongue, eyes lips, horn, teeth nose, ear lips, horn and the horns. Regional anatomy is one of the foundations of the clinical and surgical practice because it enables the clinician to visualize details of structures relevant to the case at hand (Dyce et al., 1996). Similarly, the different foramina of the skull are of clinical importance in regional anaesthesia around the head (Hall et. al., 2000).

The "Kagani" is the versatile indigenous breed of Jammu and Kashmir state of India reared mainly for meat purposes. As such no anatomical study has been conducted on morphological, craniometrical and orbitometrical aspects of the skull in this important animal yet.

This study was undertaken to establish a baseline data on the regional anatomy of the head covering its morphological and morphometrical parameters.

\section{MATERIAL AND METHOD}

In this present styudy a total number of forty six skulls of Kagani goats were utilized. The heads of these animals were selected from an abattoir based on apparent good health conditions and without any skeletal deformities. After slaughter, the heads were severed at the atlanto-occipital joint and subsequently processed by hot water maceration technique (Tasbas \& Tecirlioglu, 1996) briefly as- at first the heads were cleaned by enucleating the eyes and separating most of the skin and attaching muscles. Heads were then put in polycaboxylate solution, anionic surfactant and soap chips and heated over 80 degree for minimum 30 minutes. The heads that were boiled were then put in running tap water and the remaining muscles were detached with the help of knives. Then the skulls were put in detergent water, for about 30 minutes, which were then again subjected to removal of remaining muscles and ligaments, etc. Subsequently, the skulls were kept in $1 \mathrm{~N} 1 \%$ sodium hypochlorite solution, for 24 hours and again separation of residual muscles and ligaments were done. Then the skulls were left in the same solution for 48-72 hours and during this period, the solution was changed twice. Then, the skulls were taken out of the solution and allowed to dry. Subsequently, these were used to study their morphological features. Different craniometrical parameters were recorded with the help of measuring scale, thread and digital Vernier Callipers as under.

\section{Skull Parameters:}

a) Length: Distance between the highest point of the parietals to the middle of the rostral margin of the incisive bone.

b) Width: Distance between two zygomatic arches. 
c) Skull/cephalic index: Skull width X $100 \quad$ (Miller et al., 1964). Skull length

d) Skull base length: Distance between the midpoint of the dorsal margin of the foramen magnum to the level of the middle point on the rostral margin of the incisive bone.

e) Weight of the skull: Weight of the skull ( excluding the mandible).

\section{Cranial Parameters:}

a) Cranial length: Distance from the central point of the frontonasal suture to the middle point of the nuchal crest.

b) Cranial width: Maximum distance between the base of the horns.

c) Cranial index: Cranial width X $100 \quad$ (Miller et al.)

$$
\overline{\text { Cranial length }}
$$

d) Cranial height: Distance between the central point of the dorsal rim of foramen magnum to the point of the origin of interfrontal suture.

e) Length of the cranial cavity: Distance between the cribriform plate to the central point of dorsal rim of the foramen magnum.

f) Capacity of the cranial cavity: All the foramina of the cranial cavity were plugged with cotton. The cavity was then filled with mustard grains through the foramen magnum upto its brim. The mustard was then emptied into a measuring cylinder to get the capacity.

\section{Foramen magnum:}

a) Height: The distance between the midpoints of the dorsal ventral rims of the foramen magnum.

b)Width:The maximum distance between the two occipital condyles.

c) Area: By using the formula- $1 / 4 \mathrm{wh}$, where $\mathrm{w}=$ width and $\mathrm{h}=$ height of the foramen magnum.

d) Circumference: Length of the entire rim of the foramen magnum.

\section{Orbital parameters:}

a)Orbital length: The perpendicular distance between the supraorbital and infraorbital margins of the orbit.

b) Orbital width: The horizontal distance between the rostral and caudal margins of the orbital rim.

c) Orbital index: Orbital width X 100 (Miller et al.) Orbital length

d) Orbital depth: Distance between optic foramen and centre of the orbital rim.

e) Orbital area: $22 / 7 \mathrm{ab}$, where $\mathrm{a}$ and $\mathrm{b}$ are the halves of orbital length and width, respectively.

f) Interorbital distance:

i. At rostral level:Distance between the junction of frontolacrimal sutures of either side at the rostral margin of the orbit.

ii. At middle level:Distance between the supraorbital borders of orbit on either sides.

iii.At caudal level:Distance between the junctions of the zygomatic bone at the caudal margin of the orbit on either sides.

g) Length of the frontal: Distance from the tip of the zygomatic process of the frontal bone to the fronto-lacrimal sutures.

h) Length of the lacrimal: Distance from fronto-lacrimal sutures to the junction between the lacrimal and malar bones.

i) Length of the malar: Distance from the junction between the lacrimal and malar bones to the tip of the frontal process of malar bones.

\section{Facial Parameters:}

a) Facial length: Distance from the frontonasal suture to the centre of the incisive bone.

b) Facial width: Distance between the caudal extent of the orbital rims.

c) Facial index: Facial width X $100 \quad$ (Miller et al.)

$$
\text { Facial length }
$$

\section{Nasal parameters:}

a) Length of nasal bone: Distance from the central point of the fronto-nasal suture to the rostral end of the internasal suture.

b) Width across nasal bone: Maximum distance across the nasal bones or maximum distance between the naso-maxillary sutures.

\section{Palatine Parameters:}

a) Length of palate: Distance measured from the rostral midsutured line of incisive bone to the caudal nasal spine of the palatine bone.

b) Width of palate: Maximum distance at the horizontal plate of palatine bone behind the last molar tooth.

The data recorded were subsequently analyzed statistically for ANOVA and Regression equations (Snedecor \& Cochran, 1967)

\section{RESULTS AND DISCUSSION}

\section{Gross morphology.}

Frontal surface: This surface was constituted by the frontal, parietal, nasal and incisive bones. The frontal bone did not constitute the caudal extent of the frontal surface, rather it was formed by the parietal bone unlike in other domestic animals, where the frontal bone extended upto the caudal extent of the skull as reported in cattle (Getty, 1975), goat (Borthakur, 1990), mithun (Borthakur et al., 2000) and dum pig (Sarma et al., 2002). The frontal eminence was present on the median line, at the middle of the frontals. The interfrontal suture was serrated and fronto-nasal suture was "V" shaped (Fig. 1). The supraorbital foramina were single on either side, each lying at the dorso-lateral aspect of a roughly quadrilateral depression. These foramina were located equidistant from the interfrontal suture, approximately $2 \mathrm{~cm}$ away from the dorsal rim of the bony orbit. Borthakur reported presence of two numbers of supraorbital foramina in the skull of local goat of Assam, which could be due to breed variation. However, the supraorbital foramina were single on both the sides in sheep (May, 1970). In mithun, the supraorbital foramina were placed on a obliquely oriented supra-orbital groove (Borthakur et al., 2000). In this study, maximum width of the frontal surface was noticed at the level of the dorso-cau- 


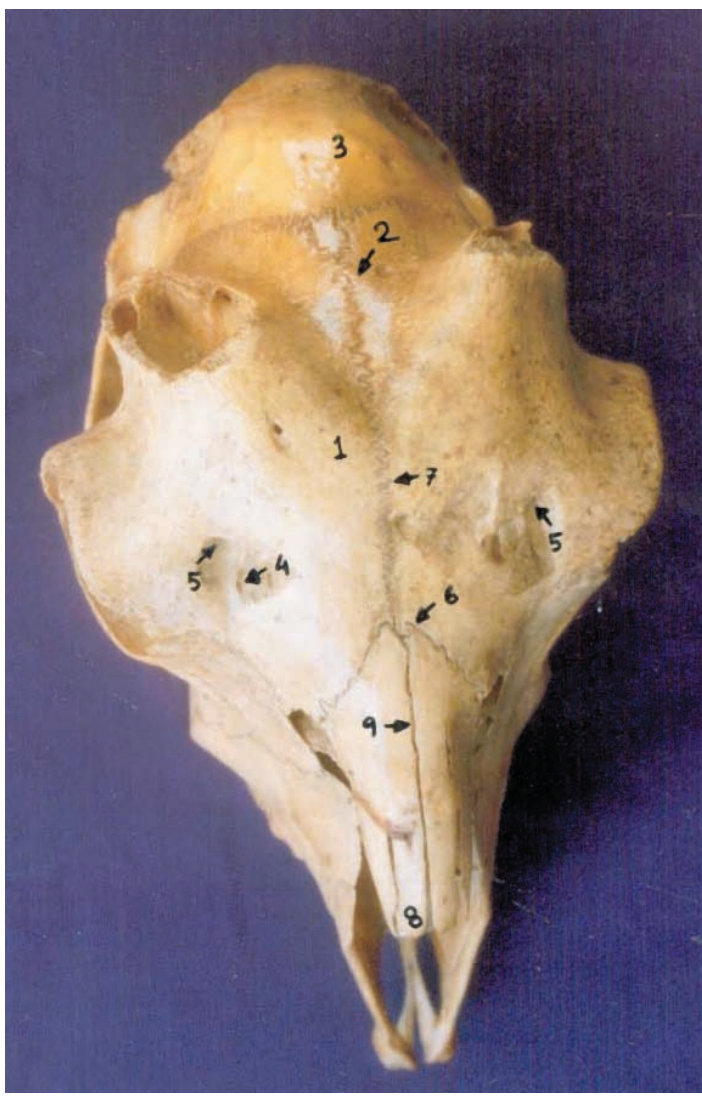

Fig. 1. Photograph of the skull of Kagani goat showing: 1. Frontal bone; 2. More zigzag interfrontal suture. 3. Parietal bone; 4. Quadrilateral area containing supraorbital foramina; 5. Supraorbital foramina; 6. Fronto nasal suture; 7. Less zigzag interfrontal suture; 8 . Broad rostral end of the nasal bone; 9 . Internasal suture. dal margin of the orbits. The nasal bones were convex at its dorsal surface, which terminated into a broad rostral end. Both the nasal bones were divided longitudinally into two halves by deep notches upto the middle part, starting from its rostral end. The internasal suture was straight. Similar findings were also reported in ox (Nickel et al., 1981) The rostral end of the incisive bone was blunt, with two long and narrow palatine fissures.

Lateral Surface: The temporal crest ended into a blunt tubercle caudo-lateral to the external auditory meatus as in cattle (Raghavan, 1964). The temporal fossa in Kagani goat was deep and extensive, whereas it was reported to be deep but short in buffalo (Sharma et al., 1990), wider in ox (Getty), shallow and elongated in Assam goat (Borthakur, 1990) and deep in yak (Archana et al., 1998). Presence of one foramen on the right and two foramina on the left side on the floor of the caudomedial aspect of the temporal fossa were noticed in the skull of Kagani goat in this study, while these foramina were 4-5 in numbers connecting the temporal canal in mithun (Borthakur et al., 2000). The facial tuberosity was placed at the junction of the $4^{\text {th }}$ and $5^{\text {th }}$ cheek teeth in Kagani goat, but the same was placed at the level of 5th cheek tooth in sheep (May), above the 3rd cheek tooth in ox, yak and mithun (Getty; Archana et al. and Borthakur et al., 2000, respectively) and dorsal to the $4^{\text {th }}$ cheek tooth in Assam goat (Borthakur). The infraorbital foramina was single on either sides, placed on a depression. Cranial to this foramen, a deep fossa was found lodging 4 numbers of foramina (Fig. 2).

The orbits were complete, oval and the rostral end of the rim was serrated. Maximum contribution to the formation of the bony orbit was by the frontals followed by the zygomatic and the lacrimals. The orbits were directed laterally as in dog, ox, horse, Assam goat, yak and dum pig

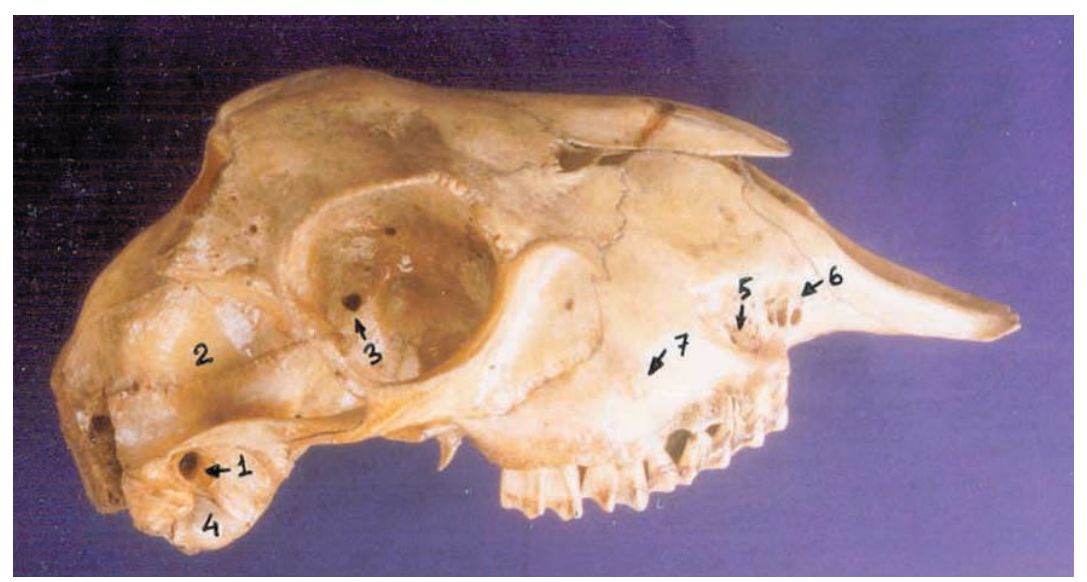

Fig. 2. Photograph of the skull of Kagani goat showing: 1. External auditory meatus: 2. Temporal fossa; 3. Optic foramen; 4. Tympanic bullae; 5. Infraorbital foramen; 6 . Deep fossa containing 4 foramina; 7 . Facial tuberosity
(Miller et al.; Getty; Hillman,1975; Borthakur; Archana \& Sharma, 1998 and Sarma et al., 2002, respectively). The basisphenpoid bone had a sharp median ridge on its body as also reported in small ruminants (Popesko, 1975).

The orbital surface of the lacrimal bone was smooth and marked off from the facial surface by a dentated orbito-facial crest. A shallow lacrimal fossa leading to a lacrimal canal was recorded just behind this crest. The foramen ovale was located in the caudal part of the pterygoid bone. 
Basal surface: It could be divided into cranial, choanal and palatine parts. The basisphenoid bone had a sharp median ridge on its body. The basilar part of the occipital bone was straight, bound rostro-caudally by two pairs of muscular tubercles, out of which the caudal pair were larger (Fig. 3). The average length of the cranial, choanal and palatine parts were were recorded as $4.2 \mathrm{~cm}, 3.9 \mathrm{~cm}$, and $10.9 \mathrm{~cm}$, respectively. The articular areas for the mandibular condyles were specious and roughly quadrilateral in shape. The tympanic bullae were laterally compressed and small. The palatine portion was "U" shaped with a straight and smooth median palatine suture (Fig. 3) The transverse palatine suture was "V" shaped and serrated, lying over the greater palatine foramina. The dorsal border of the palatine bone was perforated by the sphenopalatine foramen. The superior maxillary foramen was located approximately $1.5 \mathrm{~cm}$ above the sphenopalatine foramen. A well developed and prominent interalveolar margin was recorded in the present study which extended to the rostral margin of the maxilla as also reported in goat (Popesko).

The external occipital protuberance was located on the external lamina of the squamous occipital bone which was sharp and pointed, in contrast, it was wide and blunt in sheep (May), small and double in leopard cat (Sarma et al., 2001) and pointed in dum pig (Sarma \& Sarma, 2002).The median occipital crest was well developed in Kagani goat as recorded in the present study. The occipital condyles met at the ventral aspect of the foramen magnum forming a " $U$ " shaped intercondyloid cleft. The lambdoid suture between the parietal and occipital squamous bones was invaginated more in the middle towards the parietal bone and the coronal suture was straight.

Table I. Showing the various craniometrical measurements of the skull of Kagani goat.

\begin{tabular}{|c|c|c|c|}
\hline $\begin{array}{l}\text { Parameters } \\
\text { Skull parameters }\end{array}$ & Mean & S.E. & CV\% \\
\hline 1. Skull length & 24.72 & 0.93 & 8.39 \\
\hline 2. Skull width & 10.40 & 0.61 & 13.06 \\
\hline 3. Skull index & 41.95 & 0.97 & 5.18 \\
\hline 4. Skull base length & 23.40 & 0.71 & 6.74 \\
\hline 5. Weight of the skull (gm) & 179.50 & 1.05 & 5.23 \\
\hline \multicolumn{4}{|l|}{ Cranial parameters } \\
\hline 6. Cranial length & 7.32 & 0.23 & 6.99 \\
\hline 7. Cranial width & 4.30 & 0.25 & 13.26 \\
\hline 8. Cranial index & 58.55 & 1.54 & 5.90 \\
\hline 9. Cranial height & 16.64 & 0.42 & 5.66 \\
\hline 10. Length of cranial cavity & 11.72 & 0.66 & 12.53 \\
\hline 11. Capacity of cranial cavity & 113.0 & 0.84 & 1.66 \\
\hline \multicolumn{4}{|l|}{ Foramen magnum } \\
\hline 12. Height & 3.08 & 0.35 & 25.19 \\
\hline 13. Width & 3.12 & 0.36 & 25.78 \\
\hline 14. Area & 2.53 & 0.58 & 51.55 \\
\hline 15. Circumference & 12.3 & 0.28 & 7.57 \\
\hline \multicolumn{4}{|l|}{ Orbital parameters } \\
\hline 16. Orbital length & 5.00 & 0.13 & 6.00 \\
\hline 17. Orbital length & 4.04 & 0.18 & 10.00 \\
\hline 18. Orbital index /orbital depth & 7.25 & 0.98 & 8.72 \\
\hline 19. Interorbital distance at caudal level & 18.42 & 0.338 & 4.106 \\
\hline 20. Interorbital distance at middle level & 9.90 & 0.259 & 5.846 \\
\hline 21. Interorbital distance at cranial level & 10.14 & 0.108 & 2.375 \\
\hline 22. Length of the frontal bone forming orbital rim & 6.70 & 0.39 & 6.99 \\
\hline 23. Length of lacrimal bone forming orbital rim & 1.30 & 0.23 & 12.56 \\
\hline 24. Length of cigomatic bone forming orbital rim & 4.30 & 0.68 & 5.67 \\
\hline 25. Percentage of frontal bone forming orbital rim & 54.47 & 0.86 & 10.14 \\
\hline 26. Percentage of lacrimal bone forming orbital rim & 10.57 & 0.59 & 5.86 \\
\hline 27. Percentage of cigomatic bone forming orbital rim & 34.96 & 0.92 & 3.22 \\
\hline \multicolumn{4}{|l|}{ Facial parameters } \\
\hline 28. Facial length & 13.20 & 0.199 & 3.388 \\
\hline 29. Facial width & 18.28 & 0.244 & 2.982 \\
\hline 30. Facial index & 138.48 & 0.57 & 0.92 \\
\hline \multicolumn{4}{|l|}{ Nasal parameters } \\
\hline 31. Length of nasal bone & 6.5 & 0.11 & 1.65 \\
\hline 32. Width across the nasal bone & 3.2 & 0.57 & 5.22 \\
\hline
\end{tabular}




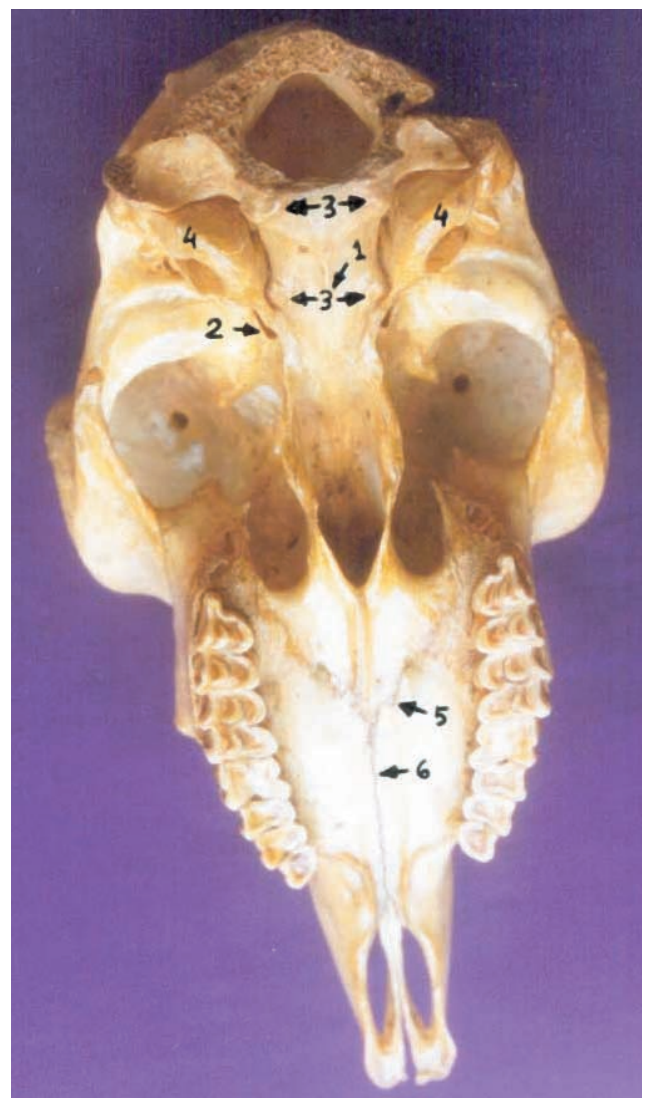

Fig. 3. Photograph of the skull of Kagani goat showing: 1. Sharp ridge on the basisphenpoid bone; 2. Foramen ovale ; 3. Muscular tubercles; 4. Tympanic bullae; 5. Transverse palatine suture; 6 . Median palatine suture.
Craniometry: The data as mean, standard error and coefficient of variation recorded in the present investigation on skulls of Kagani goat were depicted in Table I.

The mean length of the skulls were found to be 24.72 $\pm 0.93 \mathrm{~cm}$, with the width and cephalic index to the magnitude of $10.40 \pm 0.61 \mathrm{~cm}$ and $41.95 \pm 0.97 \mathrm{~cm}$, respectively.

The cranial length $(7.32 \pm 0.23 \mathrm{~cm})$ indicated a much longer facial portion than the cranial part of the skull. The orbits in Kagani goat were placed rostrolaterally formed by the frontal, lacrimal and zygomatic bones, the highest contribution in the formation of the bony orbit was by the frontals (Table I). The measurements showed that the skull in Kagani goat was elongated in shape as also reported in cattle (Rao, 1967), Assam goat (Borthakur et al., 1998) and dum pig (Sarma et al., 2002). The frontal bone contributed to the maximum in this animal as in cattle (Nickel et al.) and in yak (Archana \& Sharma).

The orbit was almost circular in shape. Various orbital parameters have been summarized in Table II which showed bilateral variation among the orbits of both the sides. The orbital length was more in left orbit, while the right orbit showed more orbital height. Similar findings were also reported in yak (Archana \& Sharma). Such bilateral variation was reported in bovine (Gupta \& Sharma, 1990), equine (Sharma \& Gupta, 1990).The orbital length was recorded more in the left orbit, while the right orbit showed more orbital height. Similarly, orbital depth and circumference were recorded more in the right orbit than the left one, while the reverse was obtained pertaining to orbital capacity.

Table II. Showing measurements of various orbital parameters of the skull of Kagani goat.

\begin{tabular}{|c|c|c|c|c|c|c|c|c|c|}
\hline \multirow[t]{2}{*}{ Parameters } & \multirow[t]{2}{*}{ Side } & \multirow[t]{2}{*}{ Mean } & \multirow[t]{2}{*}{ S.E. } & \multirow[t]{2}{*}{$\mathrm{CV} \%$} & \multirow[t]{2}{*}{ Range } & \multicolumn{4}{|c|}{ Overall } \\
\hline & & & & & & Mean & S.E. & $\mathrm{CV} \%$ & Range \\
\hline \multirow{2}{*}{ Orbital length $(\mathrm{cm})$} & Left orbit & 4.82 & 0.18 & 8.22 & $4.5-5.3$ & \multirow{2}{*}{4.74} & \multirow{2}{*}{0.17} & \multirow{2}{*}{11.22} & \multirow{2}{*}{$4.1-5.7$} \\
\hline & Right orbit & 4.66 & 0.30 & 14.60 & $4.1-5.7$ & & & & \\
\hline \multirow{2}{*}{ Orbital height $(\mathrm{cm})$} & Left orbit & 4.18 & 0.37 & 19.97 & $3.5-5.4$ & \multirow{2}{*}{4.24} & \multirow{2}{*}{0.23} & \multirow{2}{*}{17.16} & \multirow{2}{*}{$3.5-5.4$} \\
\hline & Right orbit & 4.30 & 0.31 & 16.20 & $3.7-5.2$ & & & & \\
\hline \multirow{2}{*}{ Orbital index } & Left orbit & 86.11 & 4.55 & 11.81 & $77.78-101.98$ & \multirow{2}{*}{89.12} & \multirow{2}{*}{2.49} & \multirow{2}{*}{8.83} & $77.78-$ \\
\hline & Right orbit & 92.14 & 1.64 & 3.97 & $88.37-98$ & & & & 101.89 \\
\hline \multirow{2}{*}{ Orbital depth $(\mathrm{cm})$} & Left orbit & 5.72 & 0.14 & 5.44 & $5.4-6.1$ & \multirow{2}{*}{5.82} & \multirow{2}{*}{0.08} & \multirow{2}{*}{4.49} & \multirow{2}{*}{$5.4-6.2$} \\
\hline & Right orbit & 5.92 & 0.08 & 3.02 & $5.7-6.2$ & & & & \\
\hline \multirow{2}{*}{ Orbital capacity $\left(\mathrm{cm}^{3}\right)$} & Left orbit & 22.70 & 0.75 & 7.40 & $21-24.8$ & \multirow{2}{*}{22.50} & \multirow{2}{*}{0.54} & \multirow{2}{*}{7.62} & $20.25-$ \\
\hline & Right orbit & 22.29 & 0.86 & 8.61 & $20.25-24.9$ & & & & 24.9 \\
\hline \multirow{2}{*}{ Orbita dircumference $(\mathrm{cm})$} & Left orbit & 14.14 & 0.22 & 3.52 & $13.5-14.5$ & \multirow{2}{*}{14.22} & \multirow{2}{*}{0.15} & \multirow{2}{*}{3.34} & \multirow{2}{*}{$3.5-14.9$} \\
\hline & Right orbit & 14.30 & 0.22 & 3.46 & $13.7-14.9$ & & & & \\
\hline \multirow{2}{*}{ Orbital area $\left(\mathrm{cm}^{2}\right)$} & Left orbit & 16.01 & 2.04 & 28.42 & $12.36-22.47$ & 1604 & 144 & 2832 & 11.91- \\
\hline & Right orbit & 16.05 & 2.27 & 31.59 & $11.91-23.47$ & 10.04 & 1.44 & 20.53 & 23.47 \\
\hline
\end{tabular}


Table III. Showing simple regression equations for the prediction of different unknown parameters (Y) of the skull of Kagani goat.

\begin{tabular}{|c|c|c|c|c|c|}
\hline \multirow{2}{*}{$\begin{array}{l}\text { S. } \\
\text { No. }\end{array}$} & \multirow[t]{2}{*}{ Predicted parameters $(\mathrm{Y})$} & \multicolumn{2}{|c|}{ Known parameters $X=$ Skull length } & \multicolumn{2}{|c|}{ Known parameters $X=$ Skull width } \\
\hline & & $\begin{array}{l}\text { Correlation } \\
\text { Co-efficient }\end{array}$ & Regression equation & $\begin{array}{l}\text { Correlation } \\
\text { Co-efficient }\end{array}$ & Regression equation \\
\hline 1. & Cephalic index & 0.83 & $Y=20.3933+0.8720 X$ & 0.93 & $Y=26.4428+1.4911^{*}$ \\
\hline 2. & Skull base length & 0.94 & $Y=5.6799+0.7168 X^{*}$ & 0.95 & $Y=11.9713+1.0989 X^{*}$ \\
\hline 3. & Cranial index & 0.83 & $Y=24.5326+1.3763 X$ & 0.87 & $Y=35.5074+2.2160 X$ \\
\hline 4. & Orbital depth & 0.88 & $Y=0.8399+0.2120 X$ & 0.93 & $Y=2.4724+0.3469 X^{*}$ \\
\hline 5. & Orbital index & 0.68 & $Y=44.7443+1.4544 X$ & 0.81 & $Y=52.9040+2.6723 X$ \\
\hline 6. & Interorbital distance (caudal) & 0.96 & $\mathrm{Y}=9.7708+0.3499 \mathrm{X}^{* *}$ & 0.91 & $Y=13.1776+0.5041 X^{*}$ \\
\hline 7. & Interorbital distance (middle) & 0.89 & $\mathrm{Y}=3.7874+0.2473 \mathrm{X}^{*}$ & 0.94 & $Y=5.7428+0.3997 X^{*}$ \\
\hline 8. & Interorbital distance (rostral) & 0.70 & $Y=8.1371+0.0810 X$ & 0.71 & $Y=8.8294+0.1260 X$ \\
\hline 9. & Cranial capacity & 0.92 & $\mathrm{Y}=92.4088+0.8330 \mathrm{X}^{*}$ & 0.98 & $\mathrm{Y}=98.9079+0.3374 \mathrm{X}^{* *}$ \\
\hline 10 & Cranial length & 0.88 & $Y=1.9277+0.2181 X^{*}$ & 0.90 & $Y=3.8110+0.3374 X^{*}$ \\
\hline
\end{tabular}

The skull width was positively correlated with the cephalic index, while the skull length had no such correlation. (Table III). But, skull base length varied positively with both skull length and skull width. The skull width only was positively correlated with the orbital depth in the present study, in contrast, no such correlation was recorded in buffalo (Gupta et al., 1991). The interorbital distance at the caudal level was highly correlated with skull length and correlated with skull width. A positive correlation was observed between interorbital distance at the middle level with skull length and skull width. But, the interorbital distance at the cranial level had no correlation with these parameters. The cranial capacity in Kagani goat was collinearly varied with the skull width as also observed by Archana \& Sharma in yak.

SARMA, K. Estudios morfológico y craniométrico de la cabra Kagani (Capra hircus) de la Región de Jammu. Int. J. Morphol., 24(3):449455, 2006.

RESUMEN: En el presente estudio se utilizaron 46 cabezas de cabra Kagani. El hueso frontal no constituía la parte caudal de la superficie frontal. Ambos huesos nasales estaban divididos en dos porciones por profundas incisuras en la parte media, comenzando desde su terminación rostral. La tuberosidad facial fue localizada en la mejilla, a nivel de la unión de los dientes $4^{\circ}$ y $5^{\circ}$. El hueso basiesfenoides tenía una afilada cresta mediana. El hueso frontal contribuyó ampliamente en este animal. Se registraron variaciones entre las órbitas de los lados derecho e izquierdo. La longitud de la base craneal varió positivamente respecto al ancho y largo del cráneo.

PALABRAS CLAVE : Morfología; Craniometría; Cabra.

\section{REFERENCES}

Archana Sudhakar L. S. \& Sharma, D. N. Anatomy of the skull of yak (Bos gruniens). Indian J. Vet. Anat., 10:5-9, 1998.

Borthakur, S. Post-natal study on the skull of Assam goat (Capra hircus) with an emphasis on sexual dimorphism. $\mathrm{PhD}$. Thesis submitted to Assam Agril. University, Khanapara, Guwahati-22, 1990.

Borthakur, S.; Bhattacharya, M \& Talukdar, M. Age related craniometrical study in local goat of Assam (Capra hircus). Indian J. Vet. Anat., 76:998-9, 1998.
Borthakur, S.; Sarma, K. \& Bhattacharya, M. Anatomy off the skull of mithun (Bos frontalis). Indian J. Vet. Anat. 12: 1-5, 2000.

Dyce, K. M; Sack, W. O \& Wensing, C. J. G. Textbook of Veterinary Anatomy. 2. ed. Philadelphia, Saunders, 1996.

Getty, R.(ed) Sisson and Grossman's. The Anatomy of the Domestic Animals. $5^{\text {th }}$ ed. Saunders, Philadelphia, 1975.

Gupta, S. K. \& Sharma. D. N. Biometry of bovine skull. Indian J. Anim. Res., 24 :110-4, 1990. 
Gupta, S. K; Sharma, D. N \& Bhargava, M. Cephalometry in buffalo. Himachal J. Agril. Res., 17:76-80, 1991.

Hall, L. W; Clarke, K.W \& Trim, C.M. Wright's Veterinary Anaesthesia and Analgesia. 10. ed. London, ELBS and Baillierre Tindall, 2000.

Hillman, J. D. Skull Equine, ruminant and porcine. In Sisson and Grossman's “ The Anatomy of the Domestic Animals" Getty, R. (ed). 5th edn. Saunders, Philadelphia, 1975. pp318-48 and 773-84.

May, N. D. S. Anatomy of the sheep. ${ }^{3 \mathrm{rd}}$ edn. University of Queensland Press, Australia, 1970.

Miller, M. S.; Christensen, G. V. \& Evans, H. E. Anatomy of Dog. ${ }^{2 n d}$ edn. W. B. Saunders Co., Philadelphia, 1964.

Nickel, R.; Schummer, A. \& Seiferli, E. "Anatomy of the Domestic Animals". Verlog Paul Parey, Berlin, 1981.pp 100-161.

Popesko, P. Atlas of Topographical Anatomy of the Domestic Animals. ${ }^{2 n d}$ edn. Saunders, Philadelphia, 1975. V. 1.

Raghavan, D. Anatomy of ox. Indian Council of Agricultural Research, New Delhi, 1964.

Rao, S. V. A spastic form of lameneses in adult cattle. Indian Vet. J., 44(2):170-5, 1967.

Sarma, K. ; Nasiruddulah, N. \& Islam, S. Anatomy of the skull of leopard cat (Felis bengalencis). Indian J. Anim. Sci., 71:1011-3, 2001.

Sarma, K. \& Sarma, M. Anatomy of the skull of dum pig of Assam. Indian Vet. J., 79:708-11, 2002.

Sarma, K.; Sarma, M.; Goswami, R. N ; Devi, J. \& Sarma, P. Craniometry in indigenous pigs (Sus scrofa) of NorthEast India. Indian J. Anim. Sci.. 72:13-5, 2002.

Sharma, D. N. \& Gupta, S. K. Equine cephalometry. Centaur $6: 86-9,1990$.

Snedecor, G. W. \& Cochran, W. C. Statistical Methods, Oxford and IBH Publishing Co., Bombay, 1967.

Tasbas, M \& Tecirlioglu S. Meserasyon teknigi uzerinde arasirmalar. Ank. Uni. Vet. Fak. Derg. Xll, 4:324-30, 1996.
Correspondence to:

Dr. Kamal Sarma

Division of Veterinary Anatomy \& Histology,

University of Agricultural Sciences \& Technology, R.S.

Pura, Jammu-181102

$I \mathcal{N}(\mathcal{D} I \mathcal{A}$

Email: Kamalsarma73@yahoo.com

Received: 28-03-2006

Accepted: 16-05-2006 